
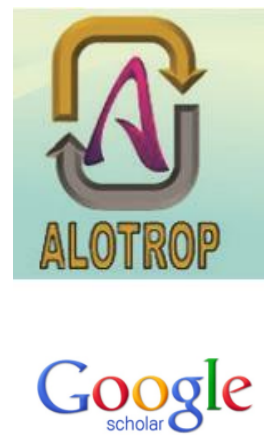

\section{ANALISIS KEMAMPUAN BERPIKIR KRITIS MATA PELAJARAN KIMIA PADA SISWAKELAS XI IPA SMAN 1 KEPAHIANG}

Selly Yunita ${ }^{1}$, Salastri Rohiat ${ }^{2}$, Hermansyah Amir $^{3}$

1,2,3 Program Studi Pendidikan Kimia Jurusan PMIPA FKIP

Universitas Bengkulu

e-mail: yunitaselly606@gmail.com

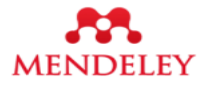

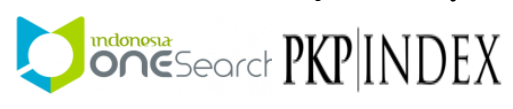

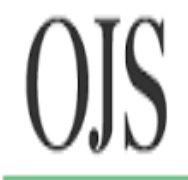

Open Journal Systems

\title{
Abstract
}

[ANALYSIS OF THE CRITICAL THINKING ABILITY FROM CHEMICAL SUBJECTS IN STUDENTS OF CLASS XI IPA SMAN 1 KEPAHIANG] This research aims to know the critical thinking ability of students. Type of this research is descriptive research using quantitative methods. This research was carried out in SMA Negeri 1 Kepahiang on September 2 to 8 may in 2017. The population in this research is the entire class XI IPA are registered on the even-numbered school year 2016/2017 semester. As the samples are taken at class XI IPA 6 of 32 participants. Data collection is done with the test in the form of reserved descriptions as much as 10 round the whole includes indicators of critical thinking from the taxonomy of Bloom that is level $\left(\mathrm{C}_{2}\right)$ understand (C3), apply (C4), analyzing and evaluating (C5). Test results obtained from the analysis of results the percentage of students with the ability to answer a question of thinking very critically at $15,6 \%$, quite critical at $53,2 \%$, and less critical at $31,2 \%$, with an average value of 61.81. From the average of the values obtained showed that students who have average value included in the category of being. Based on the analysis of the data collected can be inferred levels of critical thinking ability of the students in class XI IPA 6 SMA Negeri 1 Kepahiang at school 2016/2017 academic year can be grouped in a category group are of 53,2 \%, middle, $15,6 \%$ at high group and $31,2 \%$ at low groups. From the results, it can be concluded that overall students in grades at XI IPA 6 SMA Negeri 1 Kepahiang even 2016/2017 academic year with the ability to enough think critically.

Keywords : critical thinking, ability, Learning Results, Bloom Taxonomy.

\section{Abstrak}

Penelitian ini bertujuan untuk mengetahui kemampuan berpikir kritis siswa. Jenis penelitian ini adalah penelitian deskriptif dengan menggunakan metode kuantitatif. Penelitian ini dilaksanakan di SMA Negeri 1 Kepahiang pada tanggal 2 hingga 8 Mei tahun 2017. Populasi pada penelitian ini adalah seluruh kelas XI IPA yang terdaftar pada semester genap tahun ajaran 2016/2017. Sebagai sampel diambil pada kelas XI IPA 6 yang berjumlah 32 peserta. Pengumpulan data dilakukan dengan tes dalam bentuk soal uraian sebanyak 10 butir yang keseluruhannya mencakup indikator berpikir kritis dari taksonomi Bloom yaitu tingkat memahami $\left(\mathrm{C}_{2}\right)$, mengaplikasikan $(\mathrm{C} 3)$, menganalisis $\left(\mathrm{C}_{4}\right)$ dan mengevaluasi $\left(\mathrm{C}_{5}\right)$. Dari analisis hasil test diperoleh hasil persentase siswa dengan kemampuan menjawab soal berpikir sangat kritis sebesar 15,6\%, cukup kritis sebesar 53,2 \%, dan kurang kritis sebesar 31,2\%, dengan rata-rata nilai 61.81. Dari rata-rata nilai yang diperoleh menunjukan bahwa siswa yang memiliki nilai rata-rata tersebut termasuk dalam kategori sedang. Berdasarkan analisis data yang diperoleh dapat disimpulkan tingkat kemampuan berpikir kritis dari siswa di kelas XI IPA 6 SMA Negeri 1 Kepahiang pada semester genap tahun ajaran 2016/2017 dapat dikelompokkan pada kategori kelompok sedang sebesar 53,2 \%, kelompok tinggi 15,6\% dan kelompok rendah 31,2 \%. Dari hasil penelitian dapat disimpulkan bahwa secara keseluruhan siswa di kelas XI IPA 6 SMA Negeri 1 Kepahiang pada semester genap tahun ajaran 2016/2017memiliki kemampuan berpikir cukup kritis.

Kata kunci : berpikir kritis, kemampuan, Taksonomi Bloom, hasil belajar.

\section{PENDAHULUAN}

Perkembangan teknologi informasi pada saat ini menuntut dunia pendidikan untuk secara terus menerus meningkatkan mutu pendidikan, antara lain berupa penggunaan teknologi informasi dan komunikasi khususnya dalam proses pembelajaran [1]. Hal ini bertujuan untuk mampu menghasilkanlulusan yang berkualitas dan kreatif dalam berbagai bidang [2]. Karena itu pengelolaan pendidikan yang baik akan sangat berperan dalam menangani permasalahan moral dan pembentukan bangsa [3], walaupun terhambat banyaknya masalah yang terjadi dalam upaya pengelolaan pendidikan nasional seperti pengembangan kurikulum sekolah, proses pembelajaran, evaluasi belajar, dan ukuran keberhasilannya [4]. Permasalahan yang terjadi didalam pengelolaan pendidikan ditimbulkan akibatberbagai faktor baik internal maupun eksternal [5] baik yang bersumber dari 
siswa sendiri ataupun pada guru yang mengajar [6]. Hasil observasi dan wawancara awal di SMA Negeri 1 Kepahiang, terungkap bahwa masih terjadi permasalahan di kelas pada saat pembelajaran berlangsung. Salah satunya adalah kurangnya pemahaman siswa terhadap materi ajar, karena banyak siswa hanya mampu untuk mengetahui dan menghafal materi tanpa memahami materi yang disampaikan.Hal ini akan mengakibatkan hasil belajar siswa sukar untuk mencapai Kriteria Kelulusan Minimum (KKM) sebesar 75. Tingkat pemahaman siswa dapat diartikan sebagai tingkat kemampuan yang mengharapkan siswa agar mampu memahami arti atau konsep, situasi serta fakta yang diketahuinya [7]. Selain pemahaman konsep, kemampuan berpikir kritis dari siswa juga merupakan salah satu aspek yang perlu ditekankan dan harus mendapatkan perhatian di dalam proses pembelajaran karena akan berujung pada hasil belajar siswa [8]. Hasil belajar sendiri merupakan refleksi untuk mengetahui ketuntasan belajar siswa maupun penguasaan siswa terhadap suatu materi [9]. Kemampuan berpikir kritis sendiri dapat diartikan sebagai kemampuan siswa dalam mengidentifikasi dan merumuskan suatu problem, yang mencakup menentukan intinya, menemukan kesamaan dan perbedaan, menggali informasi serta data yang relevan, kemampuan untuk mempertimbangkan dan menilai yang meliputi membedakan antara fakta dan pendapat, dan menemukan asumsi, serta menarik kesimpulan yang dapat dipertanggung jawabkan [10]. Kualitas dari suatu proses pembelajaran dapat dilihat dari kemampuan berpikir kritis siswa pada proses pembelajaran yang dilakukan ataupun dari hasil pembelajaran siswa itu sendiri [11], karena itu agar siswa memiliki kemampuan berpikir kritis diperlukan diadakannya upaya peningkatan kualitas pembelajaran yang dilaksanakan disekolah [12].Hal ini dapat dilakukan dengan mengubah paradigma dalam pendidikan dan pembelajaran yakni orientasi pembelajaranyang semula berpusat kepada guru (tachercentered) beralih berpusat pada siswa (student centered) [13], yang bertujuan untuk dapat memperbaiki mutu pendidikan, baik dari segi proses maupunhasil pendidikan [14] Melihat pentingnya peran dari kemampuan berpikir kritis ini dalam upaya meningkatkan hasil belajar siswa maka perlu diadakan penelitian dengan tujuan mengukur tingkat kemampuan berpikir kritis siswa dari data yang diperoleh berdasarkan hasil belajarsiswa dengan menggunakan lembar tes soal uraian di SMA N 1 Kepahiang.

\section{METODE PENELITIAN}

Jenis penelitian yang dilakukan merupakan penelitian deskriptif (deskriptive research), yang ditujukan untuk mendeskripsikan suatu keadaan atau fenomena-fenomena secara apa adanya, menggambarkan secara sistematis fakta dan karakter objek atau subjek yang ditelitisecara tepat [15]. Penelitian deskriptif dilakukan dengan tujuan untuk memperoleh data. Data yang digunakan pada penelitian ini yaitu data kualitatif, yang digunakan untuk mendeskripsikan atau menggambarkan tentang kemampuan berpikir kritis siswa.

Populasi pada penelitian ini adalahseluruh siswa kelas XI IPA tahun ajaran 2016/2017 di SMA N 1 Kepahiang. Adapun kelas yang dijadikan sampel adalah siswakelas XI IPA 6 pada mata pelajaran kimia. Dalam penelitian ini instrumen untuk pengumpulan data berupa instrumen tes dengan soal uraian. Tes diberikan setelah siswa mengikuti proses pembelajaran di kelas, dengan tujuan untuk memperoleh data kemampuan berpikir kritis siswa. Analisis kemampuan berpikir kritis siswa dilakukan dengan cara mengamati dan memeriksa pekerjaan siswa atau dengan meminta penjelasan dari siswa dalam upayanya menyelesaikan masalah dalam bentuk tes soal uraian. Data yang dipilih dari hasil jawaban siswa dengan kriteria jumlah siswa yang menjawab benar tepat dengan konsep, menjawab kurang tepat dengan konsep dan tidak menjawab sama sekali dari soal yang dibuat peneliti. Hal ini dilakukan untuk melihat perbedaan tingkat kemampuan berpikir kritis siswa dari pokok bahasan dalam mata pelajaran kimia SMA.

Tabel 1.Tingkat Kemampuan Berpikir Kritis [16]

\begin{tabular}{ll}
\hline $\begin{array}{l}\text { Tingkat } \\
\text { Kemampuan }\end{array}$ & $\begin{array}{l}\text { Persentase } \\
(\%)\end{array}$ \\
\hline Tinggi & $76 \mathrm{~s} / \mathrm{d} 100$ \\
Sedang & $60 \mathrm{~s} / \mathrm{d} 75$ \\
Rendah & $0 \mathrm{~s} / \mathrm{d} 59$ \\
\hline
\end{tabular}

\section{HASIL DAN PEMBAHASAN}

Penelitian ini dilaksanakan di SMA N $1 \mathrm{Ke}-$ pahiang pada tanggal 2 hingga 8 Mei tahun 2017. 
Populasi yang digunakan adalah seluruh kelas XI IPA yang terdaftar pada semester genap tahun ajaran 2016/2017. Sebagai sampel diambil pada kelas XI IPA 6 yang berjumlah 32 peserta. Pada penelitian ini dilaksanakan setelah pokok bahasan materi koloid selesai dibahas dan dipelajari.Tes yang diberikan dimaksudkan untuk mengetahui kemampuan berpikir kritis siswa.Dimana diketahui bahwa tingkat pemahaman setiap siswa berbeda-beda. Ada 3 kategori pada persentase jumlah soal yang dijawab oleh siswa yaitu: sangat kritis, cukup kritis, dan kurang kritis. Jumlah soal yang digunakan yaitu sebanyak 10 butir soaluraian atau esay. Hal ini dapat dilihat pada tabel perhitungan persentase berikut:

Tabel 2. Persentase Tingkat Kemampuan Siswa

\begin{tabular}{lll}
\hline $\begin{array}{l}\text { Tingkat Kemampuan } \\
\text { menjawab siswa }\end{array}$ & Jumlah & $\begin{array}{l}\text { Persentase } \\
(\%)\end{array}$ \\
\hline Sangat Kritis & 5 & 15,6 \\
Cukup Kritis & 17 & 53,2 \\
Kurang Kritis & 10 & 31,2 \\
Total & 32 & 100 \\
\hline
\end{tabular}

Tabel 2 menunjukkan persentase dari jumlah hasil jawaban soal yang dapat dijawab siswa, baik itu persentase "sangat kritis", "cukup kritis" dan jumlah siswa yang menjawab soal "kurang kritis". Terlihat bahwa persentase siswa dengan kemampuan menjawab soal berpikir sangat kritis adalah sebesar $15,6 \%$, cukup kritis sebesar 53,2\%,dan kurang kritis sebesar 31,2\%.

Penelitian ini, lebih ditujukan untuk mengukur seberapa besar tingkat kemampuan berpikir kritis siswa untuk menjawab soal yang diberikan. Sehingga dapat terlihat dari hasil persentase tingkat kemampuan berpikir kritis siswa pada tabel bahwa siswa kelas XIIPA 6 memiliki kemampuan berpikir kritis dengan katagori cukup kritis, yang berarti bahwa siswamudah dalam memahami soal, dan dapat menjawab soal dengan baik serta dapat berpikir secara jelas dan tepat. Hal ini terlihat dari nilai rata-rata yang diperoleh siswa yaitu 61.81.

Terbukti dari Tabel 3 tentang kemampuan berpikir kritis siswa kelas XI IPA SMA N 1 Kepahiang untuk menjawab soal yang diuji dengan indikator berpikir kritis dari taksonomi Bloom. Setiap butir soal memiliki indikator kemampuan berpikir kritis. Rata-rata siswa menjawab setengah dari skor yang ditetapkan ini sehingga disimpulkan bahwa kemampuan berpikir kritis siswa belum mencapai kemampuan berpikir sangat kritis. Data persentase hasil tes tingkat kemampuan berpikir kritis siswa dikelompokkan berdasarkan skala persentase tingkat kemampuan berpikir kritis yang dibuat berdasarkan jumlah persentase siswa yang menjawab sangat kritis, cukup kritis, dan kurang kritis.

Tabel 3. Nilai Persentase Skor Soal Siswa

\begin{tabular}{lll}
\hline Nomor soal & Skor soal & $\begin{array}{l}\text { Rata-rata skor yang } \\
\text { diperoleh siswa } \\
1\end{array}$ \\
& 4 & 2.6 \\
2 & 9 & 7.6 \\
3 & 14 & 8.5 \\
4 & 4 & 3 \\
5 & 14 & 7.7 \\
6 & 4 & 3 \\
7 & 14 & 6.3 \\
8 & 9 & 7.4 \\
9 & 14 & 9.6 \\
10 & 14 & 5.9 \\
\hline \multicolumn{4}{c}{ Jumlah Skor } & S1.81 (Kategori \\
\hline
\end{tabular}

Jumlah siswa dengan kriteria sangat baik berjumlah $0 \%$ dengan rentang nilai $90 \leq \mathrm{A} \leq 100$ dalam penelitian ini tidak ditemukan siswa yang mencapai nilai 90 sampai dengan 100. Hasil data yang diperoleh dalam rentang $75 \leq \mathrm{B}<90$ berjumlah 15,6 \% dengan kriteria Baik. Hal ini dapat dikelompokkan ke dalam kategori kelompok tinggi.

Tabel 4. Kemampuan Berpikir Kritis

\begin{tabular}{lccc}
\hline Jumlah Siswa Yang & Menjawab & \multicolumn{1}{c}{$\%$} \\
Sangat Kritis & 5 & 15,6 & \\
\hline & & & \\
Cukup Kritis & 17 & 53,2 & \\
Kurang Kritis & 10 & 31,2 & \\
Total & 32 & & 100 \\
\hline
\end{tabular}

Pada rentang $55 \leq \mathrm{C}<75$ dengan kriteria cukup yaitu sebesar 53,2 \%, sehingga dapat dikelompokkan dalam kategori kelompok sedang. Sedangkan untuk kategori kelompok rendah berjumlah $31,2 \%$, pada kelompok sedang ada 2 kriteria hasil siswa yaitu kriteria kurang dan sangat kurang. Hal ini diperoleh dari hasil siswa untuk kriteria kurang dalam rentang $40 \leq \mathrm{D}<55$ 
yaitu sebesar 15,6\%, dan untuk kriteria Sangat kurang dalam rentang $0 \leq \mathrm{E}<40$ yaitu sebesar $15,6 \%$.

Tabel 5. Persentase Jumlah Siswa Perkriteria Kemampuan Berpikir Kritis.

\begin{tabular}{lccc}
\hline Kriteria & $\begin{array}{c}\text { Jumlah } \\
\text { Siswa }\end{array}$ & $\begin{array}{c}\text { Persentase } \\
(\%)\end{array}$ & $\begin{array}{c}\text { Rentang } \\
\text { Nilai }\end{array}$ \\
\hline A(Sangat & 0 & 0 & $90 \leq \mathrm{A} \leq 100$ \\
Baik) & & & \\
B(Baik) & 5 & 15,6 & $75 \leq \mathrm{B}<90$ \\
C(Cukup) & 17 & 53,2 & $55 \leq \mathrm{C}<75$ \\
D(kurang) & 5 & 15,6 & $40 \leq \mathrm{D}<55$ \\
E(Sangat & 5 & 15,6 & $0 \leq \mathrm{E}<40$ \\
Kurang) & & & \\
\hline Total & 32 & 100 & \\
\hline
\end{tabular}

Tabel 6. Kelompok Tingkat Kemampuan Berpikir Kritis

\begin{tabular}{lccl}
\hline $\begin{array}{l}\text { Kategori } \\
\text { Kelompok }\end{array}$ & $\begin{array}{c}\text { Jumlah } \\
\text { Siswa }\end{array}$ & $\begin{array}{l}\text { Persentase } \\
(\%)\end{array}$ & $\begin{array}{l}\text { Rentang } \\
\text { Nilai }\end{array}$ \\
\hline Tinggi & 5 & 15,6 & $76-100$ \\
Sedang & 17 & 53,2 & $60-75$ \\
Rendah & 10 & 31,2 & $0-59$ \\
Total & 32 & 100 & \\
\hline
\end{tabular}

Persentase rata-rata tingkat kemampuan berpikir kritis siswa, yaitu tingkat kemampuan berpikir kritis kelompok tinggi sebesar 15,6 \%, kelompok sedang sebesar 53,2 \%, dan kelompok rendah sebesar 31,2\% (Tabel 6). Sehingga disimpulkan bahwa siswa kelas XI IPA SMA N 1 Kepahiang TA.2016/2017 memiliki kemampuan berpikir cukup kritis hal ini dapat katakan pada kelompok sedang.

Aktivitas belajar dibutuhkan siswa agar mampu berpikir kritis dalam memecahkan masalah yang ada [17]. Seseorangyang mempunyai kemampuan berpikir kritis memiliki sikap percaya diri, sangat terbuka, menghargai sebuah kejujuran, respek terhadap kejelasan dan ketelitian, mencari pandangan-pandangan lain yang berbeda,dan akan berubah sikap ketika terdapat sebuah pendapat yang dianggapnya baik dengan kesesuaian suatu konsep yang jelas [18]. Dalam mengerjakan tes perluketelitian dan kehati-hatian karena dari siswa masih cenderung setelah menyelesaikan tes tidak diperiksa ulang, apakah masih ada soal yang belum terjawab ataupun jawaban yang kurang tepat.
Selain itu siswa juga memiliki kebiasaan sikap takut atau tidak percaya diri dalam mengerjakan tes terlihat sebelum soal tes dibagikan ada siswa sudah ingin menyerah tanpa mengetahui tes terlebih dahulu, dan tidak percaya diri dalam jawabannya sendiri sehingga menyebabkan siswa menyontek atau berdiskusi. Hal ini perlu diperbaiki karena setiap siswa harus memiliki mental yang mampu untuk siap menerima semua masalah apapun yang akan melatih pola pikir ke arah yang lebih baik dalam memecahkan permasahan tersebut dengan pemikiran yang kritis. Kemampuan berpikir kritis siswaakan berkembang apabila didu-kung dengan upaya-upaya yang dilakuan oleh guru [19]. Guru berusaha meningkatkan kemampuan berpikir kritis dengan memberikan pendapat yang berbeda, terkadang guru memberi suatu contoh dalam kehidupan sehari-hari yang berkaitan dengan materi agar siswa lebih senang dan semangat dalam mengikuti proses pembelajaran, melakukan tanya jawab agar siswaaktif dalam proses pembelajaran dan melatih siswaagar berani mengemukakan pendapatnya, memberikan bimbingan belajar/ les diluar jam sekolah, dan upaya yang terakhir adalah mendiskusikan jawaban teman agar siswa bisa bertukar pikiran dan berkomunikasi dengan temannya sehingga banyak informasi yang diperoleh siswa.

Metode ceramah, dan metode tanya jawab dianggap paling efektif dalam menjelaskan materi namun membuat siswa tidak mampu mengembangkan kemampuan berpikir kritisnya [20]. Ceramah yang baik harus divariasikan dengan metodemetode pembelajaran lain agar memungkinkan siswa aktif dalam melakukan suatu kegiatan [21]. Untuk mengontraskan proses berpikir seseorang dalam menerima atau memperoleh informasi dari pihak lain yang cenderung menerima pasif, dan membuat siswa tidak mampu mengembangkan kemampuan berpikir kritisnya. Namun, Pada saat ini siswa lebih dituntut memiliki kemampuan berpikir kritis. Oleh karena itu guru diharapkan untuk menentukan model,strategi, metode atau teknik yang digunakan guru pada kegiatan inti pembelajaran haruss esuai dengan pendekatan yang berfokus pada siswa, ranah pembelajaran, dan karakteristik mata pelajaran [22]. Latihan berpikir tingkat tinggi ini perlu dirancang olehguru sebagai pengalaman belajar siswa [23]. Salah satunya model pembelajaran yang lebih bervariasi agar melatih kemampuan berpikir kritis, sehingga siswa 
dapat memecahkan suatu masalah dengan ide-ide tanpa harus menimbulkan masalah yang baru. Hal ini dikarenakan siswa yang memiliki kemampuan berpikir kritis akan lebih mudah dalam bersosialisasi dengan lingkungan baru. Kemampuan berpikir kritis akan meningkat apabila siswa dapat dilatih dengan penerapan model seperti pembelajaran berbasis masalah [24], karena pada model pembelajaran ini akan lebih menuntut siswa untuk melakukan ekspolarasi, penemuan dan memecahkan masalah itu sendiri.

\section{KESIMPULAN}

Kesimpulan yang diperoleh dari hasil penelitian yang dilakukan adalah bahwa secara keseluruhan siswa kelas XI IPA 6 SMA Negeri 1 Kepahiang pada semester genap tahun ajaran 2016/2017 memiliki kemampuan berpikir cukup kritis berdasarkan hasil rata-rata tes diperoleh yaitu sebesar 61.81, yang termasuk dalam kategori sedang. Pada penelitian diperoleh bahwa kemampuan berpikir kritis siswakelas XI IPA 6 SMA Negeri 1 Kepahiang pada semester genap tahun ajaran 2016/2017 dapat dikelompokkan dalam kategori kelompok sedang 53,2 \%, pada kategori kelompok rendah $31,2 \%$, dan sedangkan pada kategori kelompok tinggi 15,6\%.

Sebaiknya guru dalam mengetahui tingkat pemahaman siswa, mengadakan evaluasi tertulis, dimana penilaian dilakukan dengan menggunakan lembar pengamatan pada saat proses pembelajaran berlangsung, sehingga guru dapat mengevaluasi cara mengajar terutama dalam pokok bahasan yang dianggap sulit bagi siswa.

Untuk penelitian selanjutnya sebaiknya pengambilan data dilakukan beberapa kali serta melakukan pengamatan saat pembelajaran berlangsung, seperti saat praktikum atau diskusi, karena hal ini akan lebih memperlihatkan kemampuan berpikir kritis yang dimiliki siswa dan hasil yang didapatakan akan menjadi lebih akurat.

\section{DAFTAR PUSTAKA}

1. Ginting, S.M., Hermansyah Amir., Penerapan Model Pembelajaran Somatis, Auditori, Visual dan Intelektual (SAVI) Berbantuan Media Komputer Untuk Meningkatkan Kualitas Pembelajaran Kimia Fisik II, Exacta, 2012:10(1):98105
2. Clorawati,A.R., Salastri Rohiat, Hermansyah Amir., Implementasi Kurikulum 2013 Bagi Guru Kimia di SMA Negeri Sekota Bengkulu, Alotrop, 2017 :1(2):132-135.

3. Elvinawati., Sumpono., Hermansyah Amir., Lessons Study Pada Mata Kuliah Kimia Sekolah I Sebagai Upaya Peningkatan Kualitas Pembelajaran Dan Pembangunan Karakter (Character Building), Exacta, 2012:10(2):156-159.

4. Yudi, A.A., Pengembangan Mutu Pendidikan Ditinjau dari Segi Sarana dan Prasarana (Sarana dan Prasarana PPLP), Cerdas Sifa, $2012: 1: 1-8$

5. Simanjuntak, N,D,P, Salastri Rohiat, Elvinawati., Hubungan Antara Sarana Laboratorium Terhadap Ketrampilan Proses Sains Siswa Kelas XI MIPA 5 Di SMA Negeri 3 Kota Bengkulu, Alotrop .2017:1(2):102-105.

6. Lestari, I.A, Hermansyah Amir, Salastri Rohiat, Hubungan Persepsi Siswa Kelas $X$ MIPA Di SMA Negeri Sekota Bengkulu Tahun Ajaran 2016/2017 Tentang Variasi Gaya Mengajar Guru Dengan Hasil Belajar Kimia, Alotrop, 2017: 1(2): 113-116.

7. Yonanda, D.A., Peningkatan Pemahaman Siswa Mata Pelajaran PKN Tentang Sistem Pemerintahan Melalui Metode M2M (Mind Mapping) Kelas IV MI Mambaul Ulum Tegalgondo Karangploso Malang, Jurnal Cakrawala Pendas, 2017: 3(1): 53-63.

8. Gayatri, E.R.P, Amrul Bahar, Dewi Handayani, Perbandingan Penerapan Model Pembelajaran Learning Cycle (5E) dan Two Syay Two Stray, Alotrop , 2017: 1(1):7174.

9. Viani,D.S, Amrul Bahar, Elvinawati, Perbandingan Hasil Belajar Siswa Menggunakan Media Chemopoly Game dan Tournament Question Cards, Alotrop, 2017:1(1):55-59.

10. Subiantoro, A.W., Bahrudin Fatkurohman., Keterampilan Berpikir Kritis Siswa Dalam Pembelajaran Biologi Menggunakan Media Koran , Jurnal Pendidikan Matematika dan Sains, 2009: 14(2):111-114.

11. Amalia, N.F., 2014. Pengembangan Instrumen Penilaian Keterampilan Berpikir Kritis Siswa SMA pada Materi Asam Basa. Jurnal Inovasi Pendidikan Kimia., 2014:8(2):13801385. 
12. Alifa Noora Rahma, Pengembangan Perangkat Pembelajaran Model Inkuiri Berpendekatan Sets Materi Kelarutan Dan Hasil Kali Kelarutan Untuk Menumbuhkan Keterampilan Berpikir Kritis dan Empati Siswa Terhadap Lingkungan, Journal of Educational Research and Evaluation (JERE), 2012: 1(2):133-138.

13. Wasitohadi, F.X. Sudarsono, Zamroni,, Evaluasi Implementasi Paradigma Baru Pendidikan Pasca Reformasi Pada Jenjang SD Di Kota Salatiga,, Jurnal Pembangunan Pendidikan: Fondasi dan Aplikasi, 2014:2(2):196-209.

14. Sari. J, Amrul Bahar, Dewi Handayani. , Studi Komparasi Antara Model Pembelajaran Discovery Learning dan Group Investigation Terhadap Hasil Belajar Kimia Siswa. Alotrop, 2017:1(1):60-65.

15. Arikunto, Suharsini., 2010, Prosedur Penelitian : Suatu Pendekatan Praktik (Edisi Revisi 2010 Cetakan 14) Jakarta : PT Rineka Cipta. ISBN 9789800000000

16. Arikunto, Suharsimi. 2012. Dasar-dasar Evaluasi Pendidikan, Edisi 2, Jakarta: Bumi Aksara,ISBN :978-602-217-257-4

17. Fikri. , F.N., Mardiyana., Yemi Kuswardi., Analisis Kemampuan Berpikir Kritis Dalam Pemecahan Masalah Matematika Berdasarkan Langkah-Langkah Facione Pada Materi Program Liniar Ditinjau Dari Minat Belajar Siswa Kelas XI MAN Purwodadi Tahun Ajaran 2016/2017, Jurnal Pendidikan Matematika dan Matematika (JPMM) Solusi, 2017 : 1 (2): 20-36.

18. Damanik, D.P., Nurdin Bukit, Analisis Kemampuan Berpikir Kritis dan Sikap Ilmiah Pada Pembelajaran Fisika Menggunakan Model Pembelajaran Inquiry Training (IT) dan Direct Instruction (DI), Jurnal Pendidikan Fisika, 2013:2(1):16-24.
19. Kurniasih, A.W., Scaffolding sebagai Alternatif Upaya Meningkatkan Kemampuan Berpikir Kritis Matematika, Jurnal Kreano, 2012: 3 (2) : 113-124.

20. Ilaah, YF., Yonata, B., Katerampilan Berpikir Kritis Siswa SMA Kemala Bhayangkari Surabaya Pada Materi Laju Reaksi Melalui Penerapan Model Pembelajaran Inkuiri.., Jurnal Pendidikan Kimia. 2015: 1(1):78-79.

21. Tambak, S., Metode Ceramah : Konsep Dan Aplikasi Dalam Pembelajaran Pendidikan Agama Islam, Jurnal Tarbiyah, 2014:21(2): 375-401.

22. Sunaryo, Y., Model Pembelajaran Berbasis Masalah Untuk Meningkatkan Kemampuan Berpikir Kritis dan Kreatif Matematik Siswa SMA di Kota Tasikmalaya. Jurnal Pendidikan dan Keguruan.2014: 1(2):42-43.

23. Sucipto. Pengembangan Keterampilan Berpikir Tingkat Tinggi Dengan Menggunakan Strategi Metakognitif Model Pembelajaran Problem Based Learning. Jurnal Pendidikan., 2017:2(1):63-67.

24. Hafid, A., Mengembang Kemampuan Berpikir Kritis Melalui Teknik Problem Solving. Jurnal Iktiyar, 2007: 5(3):126-129.

Penulisan Sitasi artikel ini ialah

Yunita, S., Salastri Rohiat, Hermansyah Amir, Analisis Kemampuan Berpikir Kritis Mata Pelajaran Kimia Pada Siswa Kelas XI IPA SMAN 1 Kepahiang, Alotrop, 2018:2(1):32-37. 